\title{
Consciousness of Anxiety in Literary Work of Don DeLillo
}

\section{[Vedomie úzkosti v literárnom diele Don DeLilla]}

\author{
Martina Pavlikova
}

\section{DOI: $10.18355 /$ XL.2017.10.01.07}

\begin{abstract}
Anotácia
Úzkost' a strach sú súčast'ou l'udského bytia. Literárne dielo vynimočného súčasného predstavitel'a americkej literatúry Don DeLilla sa tejto téme venuje v značnej miere. Jeho divadelné hry a viaceré romány sú meditácou o úzkosti a strachu. Zároveň ponúkajú človeku odpoved' na mnohé ontologické otázky. Táto štúdia analyzuje koncept úzkosti, strachu a smrti v literárnom diele Don DeLilla a zameriava sa na rôzne aspekty konečnosti l'udskej existencie, ktoré autor vo svojich dielach vypracoval. Tieto aspoekty zahrňujú osobnú tragédiu človeka žijúceho v konzumnej spoločnosti, útoky v New Yorku, ako aj futuristickú predstava využitia výdobytkov modernej vedy a techniky, ktorá v budúcnosti dokáže prekonat' smrtel'nost' človeka. Don DeLillo bol inšpirovaný mnohymi filozofmi a jeho dielo reflektuje prvky existencializmu.
\end{abstract}

Kl'účové slová: strach, smrtel'nost', Don DeLillo, úzkost'

\section{Úvod}

Don DeLillo (1936) je vel'mi významný a oceňovaný americký spisovatel', esejista a dramatik. Patrí $\mathrm{k}$ fenomenálnym a najvýznamnejším žijúcim prozaikom. Literárny kritik „Herold Bloom ho spolu s Philipom Rothem, Thomasom Pynchonom a Cormacom McCarthym považuje za najväčšieho amerického autora povojnovej Ameriky." (Eastes, 2013: 88) Mnohí kritici ho označujú za predstavitel'a postmodernej literatúry. Don DeLillo uvádza, že jeho tvorbu ovplyvnil hlavne „abstraktný expresionizmus, zahraničné filmy a jazz.” (DePietro, 2005: 128). Medzi autormi, ktorí ho ovplyvnili a inšpirovali v tomto období patrili James Joyce, William Faulkner, Flannery O'Connor a Ernest Hemingway. V roku 1971, na seba výrazne upozornil románom White Noise, ktorý je satirou na akademický život a zameriava sa na nepútaný konzumerizmu. Jeho unikátne dielo reflektuje koncept človeka a modernú spoločnost’ žijúcu uprostred výdobytkov vedy a techniky. (porovnaj: Hanes de Muynck, 2017: 123). V jeho tvorbe sa prelínajú moderné zariadenia, vedecké technológie, masmédiá, konšpiračné teórie. Nemenej dôležitou témou je postavenie jednotlivca $\mathrm{v}$ spoločnosti, jeho pocity zúfalstva, strachu, úzkosti, vedomie smrti a hrozba osobnej tragédie, a nespútaný konzumerizmus. V románoch Underground (Podsvetie), White Noise (Biely šum) a Falling Man (Padajúci muž) je opakujúcim sa dominantným motívom úloha masmédií a ich funkcia $\mathrm{v}$ procese formovania simulakra, ktoré má za úlohu vytrhnút' udalost' z kontextu, pozmenit' ju. Zmenou pôvodného významu nastáva nová interpretačná rovina udalosti. Don DeLillo dokáže majstrovsky literárne spracovat' tému psychológie davu, stratu vlastnej identity a rôzne formy zúfalstva človeka. Jeho divadelné hry reflektujú sú vel'kolepou meditáciou o smrti. Don DeLillove románové postavy často vnímajú potrebu konfrontovat' a prekonat' smrt'. O smrti čítajú, sledujú ju v médiách, alebo sa ju snažia prekonat' pomocou výdobytkov vedy a techniky. Vedomie smrtel'nosti a dočasnosti je neomyslitel'nou súčast'ou Don DeLillovej literárnej tvorby.

Dánsky filozof Soren Kierkegaard (1813-1855) vo svojej tvorbe (pseudonymnej ako aj pod vlastným menom) vel'mi často písal o smrti. (Buben, 2014:

$$
62
$$


129-134). Jeho filozofický vplyvna tvorbu Don DeLill je markantný v diele Falling Man. Pre Kierkegaarda, v súlade s krest'anskou interpretáciou, smrt' nie je "poslednou vecou” človeka. (Kierkegaard, 1993: 121). V neskorších spisoch smrt' je spojená s odriekaním a mučedníctvom. (Kierkegaard, 1989; Kralik - Tinley, 2017: 27-29).

Kierkegaard inšpiroval svojim konceptom smrti, utrpením a osamelost'ou a zúfalstvom nielen literátov akými boli Don DeLillo, W. H. Auden, W. Percy, M. Unamuno (Kralik - Stur, 2011), ale aj významných teológov: P. Tillicha (Kralik, 2015a, 2015b), D. Bonhoeffera (Valco, 2017) a filozofov M. Heideggera (Mitterpach, 2005) a Ortegu y Gasseta (Stur, 2011). Prvky existencializmu sa stali dôležitou súčast'ou myslenia autorov v 20. storočí a sú aktúalne aj v súčasnosti.

Don DeLillo "komentuje atmosféru, traumu Ameriky, i ducha doby, v ktorej žijeme. Často ho zaujíma úloha médií v súčasnej spoločnosti a ich schopnost' vytvorit' simularkrum reality, akúsi paralelnú rovinu, obraz, ktorý úplne zatieni skutočnost'. Z nemožnosti dozvediet' sa pravdu pramení pocit ohrozenia a následne prázdnota, ktorou DeLillovi hrdinovia často trpia a ktorá ich vyčleňuje zo šedého stredu americkej spoločnosti." (Olehla, 2014: 103).

Don DeLillove romány reflektujú svet plný strachu, neistoty a konfliktov, či už medzi kultúrami, alebo konflikt medzi jednotlivcom a spoločnost'ou. Prežitá trauma má za následok ,neukotvenost' hrdinov, existenciálnu neistotu a snahu o redefiníciu vlastnej identity. Udalost' 11. september funguje ako priedel, akýsi spúšt’ač utrpenia, z ktorého protagonisti môžu vyjst' transformovaní, očistení a zasvätení prinajmenšom zist'ujú, že zjavenie pravdy zatial' nenastalo.” (Olehla, 2014: 102).

\section{Dočasnost' l'udskej existencie}

Najvýznamnejšou básnickou zbierkou Don DeLilla je publikácia s názvom The Angel Esmeralda. V knihe sa prelínajú autorove dominantné témy akými je odcudzenie, paranoja, obava až zdesenie z pretechnizovaného sveta a komplikovanost' l'udskej komunikácie. Kniha v čitatel'ovi evokuje pocit melanchólie a prezentuje smrt' a jej rôzne aspekty ako nevynutnú súčast' l'udského bytia. Smrtel'nost' v nej má nasledovnú interpretačnú rovinu: "Ak viete, že nemáte žiadnu hodnotu, iba hazard so smrt'ou môže uspokojit' márnost' vašej existencie." (DeLillo, 2011, 80)

Dielo Falling Man (Padajúci muž) je napísané v duchu fundamentálneho záujmu o to, čo sa stane s l’ud'mi, ktorí musia žit' na následky traumy, ktorá je následkom skúsenosti a je nad limit a schopnost' ich l'udského chápania. Útoky na Obchodné svetové centrum je reflexiou absolútnej l’udskej bezmocnosti. Je tragickým uvedomením si slabosti a smrtel'nosti človeka a s ňou súvisiacu konečnost' l'udského bytia, temporaritu každého jedinca. Don DeLillove romány reflektujú svet človeka žijúceho v modernej spoločnosti, ktorý je plný strachu, neistoty a konfliktov. Domiuje vedomie smrtel'nosti a rôzne formy smrtel'nosti ktorým musí človek čelit' a následne sa s nimi vyrovnat'.

Názov diela Padajúci muž bol inšpirovaný reálnou fotografiou $\mathrm{z} 11$. septembra 2001. Na fotke je zachytený neznámy muž ako padá z vysokého poschodia Svetového obchodného centra, po tom, čo boli obe veže Svetového obchodného centra zasiahnuté a fatálne poškodené unesenými boeingami leteckých spoločností počas série útokov v USA. L’udia, ktorí ostali uväznení vo vysokých poschodiach budov, sa nachádzali nad pásmom možnosti záchrany. Pochopili, že nie je pre nich žiadna šanca na prežitie. Boli postavení pred neznesitel'nú vol'bu. Bud' ostanú v budovách a udusia sa dymom, či zaživa zhoria vo všetko pohlcujúcich a prudko silnejúcich plameňoch silného požiaru, alebo skočia z okna do hlbín priepasti pod budovami. Jediné slobodná vol'ba, ktorá im bola dopriata, bola vol'ba spôsobu smrti.

Fotografiu padajúceho neznámeho muža na druhý deň uverejnila tlač, čím bola pobúrená spoločnost'. Autor fotografie bol obvinený, že parazituje na nešt'astí 
jednej z obetí a snaží sa z tragédie urobit' senzáciu. Skutočnú identitu padajúceho muža sa nikdy s definitívnou platnost'ou nepodarilo objasnit'. (Duvall, 2011: 163)

Fotografia sa stala symbolom 11. septembra 2001. Stal sa symbolom smútku všetkých rodín, ktoré počas pádu Svetového obchodného centra prišli o príbuzných, symbolom zúfalstva a utrpenia, ktoré prinieslo smrt' a zármutok nielen americkej spoločnosti, ale aj iných národností z celého sveta. Vo Svetovom obchodnom centre pracovali aj príslušníci iných národnosti, z rozličných krajín. Tento deň „symbolizoval koniec jednej éry, pád sna o nepokoritel'nosti a nezranitel'nosti Ameriky." (Olehla, 2008: 215)

Členovia rodín obetí boli uvrhnutí do nesmierneho smútku a mnohí z nich upadli do hlbokého stavu zúfalstva. Mnohí stratili partnera a museli čelit' náhlej a nechcenej samote. Ich život, vo forme v akej ho poznali a na ktorý boli zvyknutí, prestal existovat'. Ako napísal Hajko, dánsky filozof Kierkegaard ,potvrdzuje a demonštruje úzkost', strach a skl'účenost', ktoré vyvierajú z osamotenosti jednotlivca, usiluje sa rozpoznat' híbku zúfalstva, bolesti a žial’u vyplývajúcich z nerealizovaného bytia." (Hajko, 2011: 27).

Don DeLillo kritizuje americkú spoločnost', že veže obchodného centra, ktoré postavila, svojou dominanciou a vel'kost'ou provokovali celý svet. Hlavná protagonistka románu Padajúci muž, Lianne, hovorí: „Máme teraz vlastné zrúcaniny. Ale nemyslím, že by som sa chcela na ne pozerat'." (DeLillo, 2007: 116).

Dejová línia románu Padajúci muž sa odvíja z troch rôznych uhlov pohl'adu a osobných interpretácií postáv. Jeden z hlavných protagonistov je únosca lietadla, ktoré plnou rýchlost'ou narazí do Svetového obchodného centra. Viac, než ktorýkol'vek iný autor, Don DeLillo kladie dôraz na spôsob, akým bolo formované súčasné vedomie americkej spoločnosti. Bolo to formou vojenských, informačných a spotrebitel'ské technológií. Televízne sety, automobily, lietadlá, počítače a nukleárne bomby nie sú iba predmetmi každodenného použitia. Stávajú sa akýmsi fyzickým fenoménom, ktorý umožňuje l'ud'om konat'. Umožňujú relazovat' vlastné zámery a ciele jednotlivcov. Výrazne ovplyvňujú vnímanie človeka a začleňujú sa do pamäte a identity každého jednotlivca. V niektorých prípadoch sa stávajú sa nástrojmi a symbolmi deštrukcie a smrti.

DeLillova literárna tvorba ilustruje vzájomnú symbiózu hlavných postáv a kultúrnych objektov v ktorých sa ocitli. Interakcia medzi l'udskými bytost’ami a vymoženost’ami jednotlivých moderných technológií je prítomná v každom literárnom diele Don DeLilla. Románove postavy čelia náboženským, psychologickým a existenciálnym motívom, "čelia strachu a hrôze, tápajú medzi náhodou a konšpiráciou, zmietajú sa medzi vedou a náboženstvom.” (Laist, 2010: 6). Každá z postáv subjektívne prežíva udalosti v prostredí, v ktorom sa práve nachádza a čelí rôznym formám smrti, ktorá je existenciálnym limitom ich vlastného bytia.

Jeden z únoscov sa stavia do pozície nástroja božej vôle a ospravedlňuje masovú smrt', ktorú nárazom lietadla spôsobí: “Žiadni ostatní nie sú. Ostatní existujú len do tej miery, že plnia úlohu, ktorú sme im predurčili. To je úloha ostatných. Tí, ktorí zomrú, nemajú žiadny nárok na to, aby žili, mimo užitočný akt svojej smrti." (DeLillo, 2007: 176). Únosca si vytvára vlastnú filozofiu smrti, ktorou ospravedlňuje svoj čin a povyšuje poslanie jednotlivca nad smrt' masy, ktorú označuje pojmom 'tí ostatní." Označuje tak dav, masu, ktorú považuje za nepodstatnú a je presvedčený, že "tí ostatní" sú nepravda. Tí ostatní sú len davom a bezduchou masou, nežijú pravdu spravodlivosti a preto nemajú právo na život. Dánsky filozof Kierkegaard v Konečnom nevedeckom dodatku k Filozofickým omrvinkám zdôrazňuje, že "subjektívny myslitel' je práve tak negatívny ako aj pozitívny, a má v sebe rovnako vel'a komickosti ako aj nevyhnutného pátosu" (Kierkegaard, 1992: 80).

M. A. verí, že svojim, podl'a vlastného presvedčenia náboženským skutkom v mene boha, dosiahne nesmrtel'nost'. Únoscovia vedia, že zomrú, ale vo svojej 
konečnosti a postoji k svojej smrti vidia zásadný rozdiel: "My sme ochotní zomriet', oni nie. V tom je naša sila, pretože my milujeme smrt" (DeLillo, 2007, 178).

Don DeLillo kriticky konštatuje, že veže Svetového obchodného centra boli predurčené k pádu: “Ale práve preto sa tie veže stavali, nie? Neboli snád' tie veže postavené ako symboly bohatstva a moci, ktoré sa jedného dňa stanú symbolom deštrukcie? Taká vec sa stavia preto, aby sa človek mohol pozerat' ked' bude padat' k zemi. To je jasná provokácia. Aký iný dôvod tu môže byt', aby boli tak vysoké a ešte $\mathrm{k}$ tomu všetkému dve? Je to symbol, tak prečo nie hned' dvojnásobný? Ved' tím priamo hovoríte: Tu sú, zborte ich" (DeLillo, 2007: 116).

Don DeLillove diela hl'adajú východisko z všadeprítomného strachu, ktorému musí človek modernej doby čelit’. Uvedomujúc si, že konzumerizmus produkuje spoločnost' l'udí, ktorí v skutočnosti nemajú záujem o svojho blížneho, jeho postavy hl'adajú samotu a naplnenie zmyslu života $\mathrm{v}$ rôznych očistných rituáloch. Hladajú vlastnú morálnu autenticitu, osobnú skúsenost', pretože ich konzumerizmus prestal naplňovat' (Kondrla - Repar, 2017: 23). Blízkost' smrti v nich vyvoláva hrôzu a do vedomia neustále vnáša prítomnost' smrtel'nosti. Ako poznamenala Gabašová: "Strach, úzkost', zúfalstvo, nádej, súcit a zármutok sa spájajú s emóciami, ktoré v človeku smrt' a vedomie smrtel'nosti vyvolávajú. Čelit' akejkol'vek kríze môže spôsobit' rezignáciu na zmysel či absenciu motivácie do života. Nádej je východiskom, hybnou silou, akousi túžbou po zmysle, ktorú stotožňujeme s vierou. Nádej tak môže nadobúdat' rôzne podoby - mýtus, doktrína, náboženský alebo svetský rituál, konvencie v spoločnosti.” (Gabasova, 2014: 41).

Keith sa po traumatických udalostiach v New Yorku, ktorých bol očitým svedkom, nedokáže začlenit' do normálneho spoločenského života. Na rozdiel od Lianne, nedokáže zmenit' svoj život a začat' žit' zmysluplne. Postupne stráca sám seba a kontrolu nad vlastným životom. „A to je na živote l'udí smutné - mnohí z nich žijú svoj život v tichom poblúdení; vyžívajú sa sami, nie v tom zmysle, že by sa obsah života postupne rozvíjal a oni seba vlastnili v tomto rozvinutí, vyžívajú sa takpovediac sami zo seba, miznú ako tône, ktorým odvialo nesmrtel'nú dušu. Nestarostia sa pri otázke jej nesmrtel'nosti a rozplynú sa vlastne ešte prv, ako zomrú." (Kierkegaard, 2007: 624).

\section{Aspekty konečnosti l'udského bytia}

Smrtel'nost' je súčast'ou l'udského bytia. Je symbolom konečnosti, existenciálneho limitu každého človeka a „predstavuje zložitý konštrukt pozostávajúci z vymedzenia pojmu vedomie a smrtel'nost'. V tomto spojení nadobúda termín širšie významové pole, zahŕňajúce stavy nevedomia. Vedomie smrtel'nosti používame v terminológii vo význame schopnosti uvedomenia si vlastnej konečnosti, temporality vo vedomí" (Gabasova, 2014: 20).

Daniel Greenspan zastáva názor, že DeLillove dielo Padajúci muž opisuje niekol'ko foriem vedomia smrti."(Greenspan, 2013: 88) a následne objasňuje: "Niektoré prezentujú jej nevyhnutnost' a transcendentnost", iné "redukujú smrt' na niečo, čo môže byt' posudzované z l'udského hl'adiska. Jednotlivci môžu byt' zničení extatickými emóciami, ako je napríklad láska, alebo hrôza.” (Greenspan, 2013: 88).

$\mathrm{V}$ jednej $\mathrm{z}$ dejových hlavná protagonistka románu, diskutuje so svojou umierajúcou matkou o obraze maliara Giorgia Morandiho. Mal'ba má názov Natura Morta (Zátišie) a paradoxne im svojou kompozíciou pripomína pád veží Obchodného Svetového Centra. Navzdory osobného nesúhlasu sa Liannina matka pýta: "Všetko je to o smrtel'nosti, či nie?", na čo L. odpovedá: "O l'udskosti." Jej matka smutne konštatuje: “O l'udskosti a smrtel'nosti” (DeLillo, 2007: 111). Smrtel'nost' je súčast'ou l'udskej existencie a každý človek jej musí čelit'.

$\mathrm{V}$ inej časti dejovej línie únoscovia vedia, že zomrú, ale vo svojej konečnosti a postoji voči tejto forme smrti vidia zásadný rozdiel: "My sme ochotní 
zomriet', oni nie. V tom je naša sila, pretože my milujeme smrt'." (DeLillo, 2007: 178).Takéto tvrdenie vyjadruje vol'bu jednotlivca, ktorý čelí smrtel'nosti a vie, že nastane smrt' nielen tých ostatných, ale aj jeho vlastná. Únoscovia prežívajú extatické vzrušenie z kolektívnej smrti a láska k smrti sa stáva ich hybnou silou. Ich jedinou poslednou vol'bou bola možnost' hodit' sa do hlbín pod vežami, alebo uhoriet' v plameňoch, ktoré prudko silneli po náraze lietadiel do veží obchodného centra. Stále prítomné vedomie smrtel'nosti dominuje aj v iných pasážach románu Padajúci muž. Don DeLillo zdôrazňuje nevyhnutnost' smrti každej l'udskej bytosti.

$\mathrm{V}$ ostrom kontraste sú útočníci komanda smrti a ich zmýšl’anie. Sú presvedčení, že ich životné poslanie bolo splnené, že dosiahli zaslúbenú spásu v tom okamihu, kedy lietadlo narazilo do jednej z veží Svetového obchodného centra. Podobný koncept, v rámci 11. septembra, bol rozpracovaný v diele amerického literáta Johna Updika.

Kontroverznou postavou DeLillovho románu je pouličný umelec, ktorý sám seba prezentuje pod umeleckým menom Padajúci muž. Svojim umeleckým predstavením znázorňuje pád muža zo Svetového obchodného centra. Má na sebe oblek, košel'u a kravatu a jeho znázornenie je reprodukciou kontroverznej fotografie pádu muža $\mathrm{z}$ jednej $\mathrm{z}$ budov, ktoré v obecenstve vyvoláva emócie zúfalstva, hnevu a bezmocnosti. Tento imidž smrti sa stáva nemým a zúfalým výkrikom protestu proti $\mathrm{v}$ New Yorku. Je nemým svedkom a pripomienkou traumy, hrôzy, úzkosti a strachu: "Ludia na neho kričali, pobúrení tým predstavením, bábkovým divadlom l'udského zúfalstva, posledným výdychom letiaceho tela, pobúrení tým odkazom. Prit’ahuje $\mathrm{k}$ sebe oči celého sveta, pomyslela si. Tá hrozná otvorenost', zobrazenie toho, čo sme nevideli, jedinej padajúcej postavy, ktorá vlečie so sebou spoločný strach, telo, ktoré dopadlo medzi náš všetkých" (DeLillo, 2007: 33).

Don DeLillo v románe Cosmopolis prezentuje iný typ tragédie. Je to osobná tragédia, ktorá taktiež dokáže človeka zničit'. Hlavným protagonistom románu je multimilionár E.P. ktorý zbohatol prostredníctvom obchodovania s cennými papiermi na burze. Je produktom "novej ekonomiky", majitel' superluxusnej limuzíny vybavenej obrazovkami. Taktiež je majitel’om luxusného bytu. Na základe špekulácie možného vývinu situácie na burze, sa jedného dňa rozhodne vsadit' všetky svoje peniaze na pokles kurzu jenu. Avšak táto špekulácia nepotvrdí správnost' jeho rozhodnutia. Japonský jen na trhu neklesá, naopak, darí sa mu. Tým sa udalosti v priebehu jedného dňa zmenia na katastrofu, ktorá so sebou prináša osobnú tragédiu.

E.P. si zúfalo uvedomuje, že burza sa nechová podl'a očakávania, ani podl'a zažitých pravidiel. Miesto toho, aby racionálne uvažoval a situáciu na burze riešil predajom podielov a akcií, upadá do hlbokej osobnej ekonomickej krízy a fyzickej autodeštrukcie. Z prít’ǎlivého mladého muža, $\mathrm{Z}$ reprezentanta amerického rozprávkového bohatstva sa stáva úplná troska, ktorá nakoniec umiera rukou vraha. Zomiera takou formou smrti, ktorej sa celý život obával. Jeho paranoidné predstavy sa napínajú. Smrt' prichádza v podobe bývalého zamestnanca Benna Levina, ktorý svoj čin považuje za násilný akt, ktorý vojde do histórie a zmení všetko.

Multimilionár prežíva osobnú tragédiu, formu násilného zjavenia spravodlivosti, akúsi formu konečnej pravdy. Bývalý zamestnanec sa stáva jeho “osobným Anjelom smrti” (Cowart, 2002: 221). V tomto románe Don DeLillo neprezentuje koniec sveta v zmysle konca l’udstva a všetkého, čo je živé. Prezentuje osobnú tragédiu, ktorá je pre jednotlivca čisto individuálna. Zaznamenáva nezvratný a strmý pád človeka, ktorý dosiahol vrchol svojich ambícií a následne spadol až na osobné dno, kde musel čelit' vlastnej temporarite. Hlavný protagonista románu sa smrti vždy vel'mi bál. Počas hedonistického a konzumného života zaháňal myšlienky na smrt', ale zároveň nad ňou musel premýšl'at'. 'L'udská bytost' ako jediná rieši otázky súvisiace so životom a smrtou. Tendencie $\mathrm{v}$ súčasnej spoločnosti sú protichodné, napokon, tak tomu bolo vždy. Na jednej strane je smrt' vytesňovaná v 
zmysle, že človek sa na smrt' snaží nemysliet', dokonca je až tabuizovaná, na druhej strane je ňou jednako fascinovaný, túži ju prekonat', zvít'azit' nad ňou, spoznat' ju, pochopit' a vysvetlit'. Východiskom je problém strachu a tendencia vytesňovania smrti na okraj záujmu, vedomé potláčanie myšlienky na vlastnú konečnost'.” (Gabasova, 2014: 9).

DeLillov najnovší román Zero K bol publikovaný v roku 2016 a je autorovou vel'kolepou meditáciou o smrti. Hlavný protagonista miliardár Ross Lockhart sa snaží bojovat' so smrtou a zachránit' svoju mladú manželku, ktorá má nevyliečitel'nú chorobu. Vel'kú čast' majetku investuje do výskumného strediska, v ktorom pomocou moderných technológií smrt' vnímaju ako kultúrny artefakt, nie striktnú determináciu toho, čo je l’udsky neodvratné (DeLillo, 2016: 71). Smrt' je ovládaná a telá sa uchovávajú až do doby, ked' budú schopné človeku ponúknut' vyššiu kvalitu života. Don DeLillo nastol'uje niekol'ko fundamentálnych otázok: "Rodíme sa bez toho, aby sme si to vybrali. Máme rovnako tak aj umriet?" (DeLillo, 2016: 252). Don DeLillo sa taktiež pýta: "Nie je vlastne hrdinstvom človeka odmietnut' svoj osud?" (DeLillo, 2016: 253). Autor taktiež ponúka novú perspektívu pohl'adu na smrt'. "Nie je smrt' v konečnnom dôsledku požehnaním? Nie je práve smrt' tým, čo určuje skutočnú kvalitu života a robí ho hodnotným? (DeLillo, 2016: 69).

\section{Záver}

Unikátne dielo súčasného amerického spisovatel'a Don DeLilla reflektuje koncept človeka a modernú spoločnost’ žijúcu uprostred výdobytkov vedy a techniky. $\mathrm{V}$ jeho diele dominujú prvky filozofie existencializmu. Existencializmus je prítomný $\mathrm{v}$ literárnych dielach dvadsiateho storočia. Dôležitou témou je postavenie jednotlivca v spoločnosti, jeho pocity zúfalstva, strachu, úzkosti a vedomie konečnosti l'uskeho bytia. Smrt' a jej rôzne aspekty sú dominantnou črtou jeho literárnej tvorby. Autor smrt' neadoruje. Vníma ju ako jeden z elementárnych atribútov l'udskej existencie. Predstiera jej rôzne aspekty a formy v konzumnej spoločnosti l'udí. Don DeLillo naznačuje, že práve hazard so smrtou sa pre jednotlivca môže stat' jediným uspokojením márnosti existencie. Zároveň naznačuje, že smrt' može byt' požehnaním a byt' tým, čo robí život človeka hodnotným. Spochybňuje futuristické predstavy o možnosti smrt' oklamat' výdobytkom modernej techniky a dokonca ju úplne odstránit' zo života l'udí. Autorove literárne dielo reflektuje vel'kolepé meditácie o úzkosti, strachu a smrti.

\section{Bibliograpic references}

AMINEVA, V. R. 2014. «Universal» and «Unique» as the Categories of Comparative Literature. Middle-East Journal of Scientific Research, n. 20 (12), pp. 2094-2098. ISSN 1990-9233

BUBEN, A. 2014. "Death”. In: Kierkegaard's Concepts, Tome II: Classicism to Enthusiasm, ed. by Steven Emmanuel, William McDonald, and Jon Stewart, (Kierkegaard Research: Sources, Reception and Resources, vol. 15). Aldershot: Ashgate, pp. 129-134. ISBN 9781472428394.

COWART, D. 2002. Don DeLillo - The Physics of Language. Athens: University of Georgia Press. ISBN 978-0820323206

DeLILLO, D. 2011. The Angel Esmeralda: Nine stories. New York: Simon and Schuster. ISBN 9781451658071.

DeLILLO, D. 2007. Falling Man. New York: Scribner. ISBN 978-1-4165-4606-1.

DePIETRO, T. (Ed.) 2005. Conversations With Don DeLillo. Mississippi: University Press of Mississippi. ISBN 1-57806-704-9. 
ESTES, A. K. 2013. Cormac McCarthy and the Writing of American Spaces, Radopi, New York, 2013. ISBN 9789042036291.

DUVALL, J. N. 2011. Witnessing Trauma: Falling Man and Performance of Art, pp. 152 - 168. In: Don DeLillo: Mao II, Underworld, Falling Man, Ed. Stacey Olster, New York, Bloomsbury Publishing, ISBN 1441106243.

HAJKO, D. 2011. Vrucnost a cin. Kierkegaardovske meditacie. Bratislava: Hajko \& Hajkova, 2011. ISBN 978-80-88700-78-4.

HANES, P. - DE MUYNCK, B. Deification of Technology and the Dignity of the Hunan Person. In: Komunikacie, vol. 19, n. 1, pp. 121-125. ISSN 1335-4205.

GABASOVA, K. 2014. Kierkegaard a obraz smrti vo svetle sucasnosti. Ljubljana: KUD APOKALIPSA, 2014. ISBN 978-9-616-89459-3.

GREENSPAN, D. 2013. Don DeLillo: Kierkegaard and the Grave in the Air. In: Kierkegaard's Influence on Literature, Criticism and Art: The Anglophone World. Kierkegaard Research: Sources, Reception and Resources Farnham: Ashgate, pp. 81100. ISBN 978-1-4094-5763-32-01-3.

KIERKEGAARD, S. 1993. Bazen a chveni. Nemoc k smrti. Prague: Nakladatelstvi: Svoboda - Libertas. ISBN 80-205-0360-9.

KIERKEGAARD, S. 2007. Bud - alebo. Bratislava: Kalligram. ISBN 80-7149-913-7. KIERKEGAARD, S. 1989. Cistota srdce aneb chtit jen jedno. Prague: Kalich. ISBN 80-7017-036-0.

KIERKEGAARD, S. 1992. Concluding Unscientific Postscript To Philosophical Fragments. Ed. and transl. Howard V. Hong \& Edna H. Hong. Vol. I. Princeton: Princeton University Press. ISBN 0-691-02081-7.

KONDRLA, P - KRALIK, R. 2016. The specifics of mission of the thessalonian brothers and the potential for their actualization $=$ Specifika misie solunskych bratov a ich aktualizacny potecial. 2016. In: Konstantinove Listy, vol. 9, n. 2, pp. 90-97. ISSN 1337-8740.

KONDRLA, P. - REPAR, R. 2017. Ontological Consequences of the Ethics of Technology. In: Komunikacie, vol. 19, n. 1, pp. 19-24. ISSN 1335-4205.

KONDRLA, P. - REPAR, P. 2017. Postmodern Aspects of New Religious Movements. In: European Journal of Science and Theology, vol. 13, n. 3, In print. ISSN 1841-0464.

KRALIK, R. 2015a. Key Philosophical -Theological Concepts of Soren Kierkegaard in the Work of Paul Tillich. In: European Journal of Science and Theology, vol. 11, n. 4, pp. 179-188. ISSN 1841-0464.

KRALIK, R. 2015b. Kierkegaard and His Influence on Tillich's Philosophy of Religion. In: European Journal of Science and Theology, vol. 11, n. 3, pp. 183-189. ISSN 1841-0464.

KRALIK, R. 2013. The Reception of Soren Kierkegaard in Czech Language Writings. In: Filosoficky casopis, vol. 61, n. 3, pp. 443-451. ISSN 0015-1831.

KRALIK, R. 2013. Marie Mikulova Thulstrup (1923-2013) and her work. In: Filosoficky casopis, vol. 61, n. 3, pp. 439-442. ISSN 0015-1831.

KRALIK, R. - PAVLIKOVA, M. 2013. The Reception of Kierkegaard's Thought in Slovakia. In: Filozofia, vol. 68, n. 1, pp. 82-86. ISSN 0046-385X.

KRALIK, R. - STUR, M. 2011. Unamuno a Kierkegaard - filozofovia a rebeli. In: Kierkegaard as Challenge to the Contemporary World-Kierkegaard ako vyzva $\mathrm{k}$ sucasnemu svetu: Acta Kierkegaardiana - Supplement 2. (Eds. Roman Kralik et al.) Toronto: Kierkegaard Circle, University of Toronto, pp. 272-280. ISBN 978-09809365-5- 1.

KRALIK, R. - TINLEY, S. J. 2017. Kierkegaard's Ethics as an Answer to Human Alienation in Technocratic Society. In: Komunikacie, vol. 19, n. 1, pp. 25-29. ISSN 1335-4205. 
LAIST, R. 2010. Technology and Postmodern Subjectivity in Don DeLillo's Novels. New York: Peter Lung Publishing. ISBN 978-1-4331-0841-9

MITTERPACH, K. 2005. Landscape and horizon (The significance of the problematic of space in Heidegger's 'Being and Time'). In: Filozofia, vol. 60, n. 6, pp. 454 - 460. ISSN 0046-385X.

MULLER, C. 2009. Fate and Terror in Don DeLilloes Falling Man. In: Engaging Terror: A Critical and Interdisciplinary Approach (Human Condition). Vardalos, M. (Ed.) Letts, G.K. (Ed.) Teixeira, H. M. (Ed), Karzai, A. (Ed), Haig, J. (Ed). Florida: Brown Walker Press. ISBN 978-1-59942-453-8.

OLEHLA, R. 2008. Doslov. In: Padajici muz. Don DeLillo. Prague: Odeon, 2008, pp. 215 -224. ISBN 978-80-207-1282-0.

OLEHLA, R. 2014. Perspektivy konce: Thomas Pynchon a americky roman po 11. zari. Prague: Univerzita Karlova v Praze, ISBN 978-80-246-2502-7.

PAVLIKOVA, M. 2017. Kierkegaard's Reflection in Don DeLillo's Novel 'Falling Man'. In: European Journal of Science and Theology, vol. 13, n. 1, pp. 15-23. ISSN 1841-0464.

PISONOVA, M. 2016. Philosophical Explication of Requirements on the Process of Education - Novelty or Relic? In: XLinguae, vol. 9. n.1 pp. 83-90. ISSN 1337-8384.

REPAR, P. 2012. Existencialna dialektika rozhodnutia a skandalon. In: Filozofia, vol. 67, n. 8, pp. 689-702.

STUR, M. 2011. Zodpovednost a sensus communis u Unamuna, Ortegu y Gasseta a Heideggera $=$ Responsibility and Sensus Communis at Unamuno's, Ortega y Gasset's and Heidegger's Work. In: XLinguae, vol. 4, n. 4, pp. 30-39. ISSN 1337-8384.

SHAIDULLINA, A. R. - EVSYUKOVA, N. Y. - MIKHAILOV, V. A. GAZIZOVA, F. S. - MASALIMOVA, A. R. - KHAIRULliNA, E. R. GALIMZYANOVA, I. I. (2015). The Curriculum Project on Professional and Pedagogical Teachers? Communication Culture Formation. Mediterranean Journal of Social Sciences, 6(2 S3), 202-208.

VALCO, M. 2017. The Value of Dietrich Bonhoeffer's Theological-Ethical Reading of Soren Kierkegaard. In: European Journal of Science and Theology, vol. 13, n. 1, pp. 47-58. ISSN 1841-0464.

VALCO, M. - BOEHME, A. J. 2017. Christian Faith and Science: Can Science Enhance Theology? In: European Journal of Science and Theology, vol. 13, n. 3, In print. ISSN 1841-0464.

VALCO, M. - KRALIK, R. - BARRETT, L. 2015. Moral implications of Augustine's Philosophical and Spiritual Journey in his Confessiones, In: Komunikacie, vol. 17., n. 2, pp. 103-108, ISSN 1335-4205.

ZAGIDULLINA, D.F. - AMINEVA, V.R. 2016. Avant-Garde Research in the Field of Verse Forms (based on I.Yuzeev lyrics). In: XLinguae. vol. 9. n. 1. pp. $135-145$. ISSN 1337-8384.ZALEC, B. 2017. Preferential and Non-preferential Love in Light of Kierkegaard's Thought. In: European Journal of Science and Theology, vol. 13, n. 2, pp. 179-189. ISSN 1841-0464.

Words: 3993

Characters: 27653 (15,36 standart pages)

PhDr. Martina Pavlikova, PhD.

Department of Journalism

Constantine the Philosopher University in Nitra

B. Slanickovej 1, 94901 Nitra

Slovak Republic

mpavlikova@ukf.sk

69 